九州大学学術情報リポジトリ

Kyushu University Institutional Repository

\title{
Repression of the Propagation of Ehrlich Ascites Tumors by Means of Attenuating Tumor Cells. III
}

Suiko, Masahito

Laboratory of Pesticide Chemistry, Faculty of Agriculture, Kyushu University

Maekawa, Kazuyuki

Laboratory of Pesticide Chemistry, Faculty of Agriculture, Kyushu University

https://doi.org/10.5109/23489

出版情報: 九州大学大学院農学研究院紀要. 21 (2/3)，pp.91-98，1977-03. Kyushu University バージョン：

権利関係 : 
J. Fac. Agr., Kyushu Univ., 21, 91-98 (1977)

\title{
Repression of the Propagation of Ehrlich Ascites Tumors by Means of Attenuating Tumor Cells. III
}

\author{
M asahito Suiko and Kazuyuki Maekawa \\ Laboratory of Pesticide Chemistry, Faculty of Agriculture, \\ Kyushu University 46-02, Fukuoka 812
}

(Received November 15, 1976)

\begin{abstract}
Aminoethyl ether of amylose (AEA) and aminoethyl ether of glycol cellulose (AEC) in which the degree of polymerization was about 20-25 were mixed respectively with yeast RNA to produce stable complexes. The complexes dissociated about $5 \%$ at $\mathrm{pH}$ 4, while they were almost insoluble at neutral $\mathrm{pH}$. The complexes were hydrolyzed about a half by pancreatic RNase A. When Ehrlich ascites tumor cells were incubated with these complexes, the transplantability of those cells in mice were almost completely abolished. The mice pretreated thus became strongly resistant to a challenge inoculation afterwards. The effectiveness of AEA and AEC as a combining moiety was similar.
\end{abstract}

It has already been reported that treatments with an MA: y-RNA complex or clay: y-RNA complex etc. are useful for attenuating Ehrlich ascites tumor cells (Maekawa and Kushibe, 1972; Maekawa and Momii, 1972; Takakuwa et al., 1975). However, the results were sometimes unsteady.

The present experiment was therefore undertaken to find a more suitable and reliable method for attenuating tumor cells. As such a compound like that the complex formed with the RNA moiety is set free for the first time on the surface of tumor cells to reveal the cytotoxicity, aminoethylamylose and aminoethylcellulose were chosen and scrutinized in regard to their attenuating effects and other biological activities on E-cells.

The complexes were composed of both polysaccharide derivatives and $y$ RNA dissociated about $5 \%$ at $\mathrm{pH} 4.1$, which was the isoionic point of the tumor surface (Straumfjord and Hummel,1959), so that these substances were likely to be suitable for investigating mild attenuation of E-cells.

\section{EXPERIMENTAL}

\section{$M$ aterials and $M$ ethods}

1) $A E A$ and $A E C$

AEA and AEC were synthesized according to the procedure of Higuchi et al. (1970). The average degree of polymerization(n) was estimated by a colloid titration method as follows: AEA, 20-25; AEC, 25 and 100. The degree of substitution(DS) was 1.3 for the former, 1.7 and 1.25 for the latter. y-RNA was prepared as described previously (Maekawa and Kushibe, 1972). 


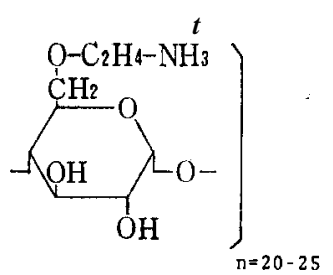

AEA

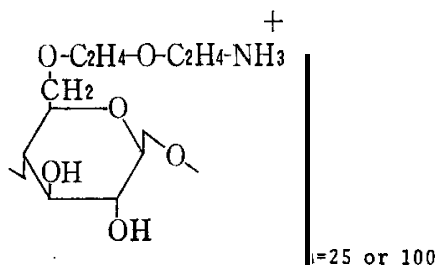

AEC

Scheme 1. AEA and AEC.

\section{2) Complex formation of AEA or AEC with $y-R N A$}

A preparation of AEA and y-RNA complex (AEA: y-RNA) or AEC and yRNA complex (AEC: y-RNA) was carried out as follows. Both AEA and AEC were soluble in water, their aqueous solutions being $\mathrm{pH} 10-11$. These solutions were initially adjusted to $\mathrm{pH} 7.0$ with $0.1 \mathrm{~N}$ acetic acid. The complexes were then formed by gradually adding neutralized AEA or AEC solution to excess amounts of y-RNA solution which was previously dissolved in $0.9 \%$ $\mathrm{NaCl}$. After stirring for $30 \mathrm{~min}$. at room temperature, the mixtures were centrifuged. The precipitates were washed thoroughly with $0.9 \% \mathrm{NaCl}$. From the difference between $A_{260 \mathrm{~nm}}$ of the supernatant (including washed solution) and that of the starting quality, the amount of RNA which took part in the complex formation was estimated. The combining ratio was evaluated as described in the previous paper. The results are given in Table 1.

Table 1. Complex formation of AEA or AEC with y-RNA.

\begin{tabular}{ccccccc}
\cline { 5 - 6 } Polymer & $\begin{array}{c}\text { Mol. wt. } \\
\text { of hexose } \\
\text { unit }\end{array}$ & $\begin{array}{c}\text { Degree of } \\
\text { polymeri- } \\
\text { zation }\end{array}$ & $\begin{array}{c}\text { Mol. wt. } \\
\text { of } \\
\text { polymer }\end{array}$ & $\begin{array}{c}\text { KNA } \\
\text { combined } \\
\text { with } \\
\text { polymer } \\
\text { (g/g) }\end{array}$ & $\begin{array}{c}\text { Combined } \\
\text { RNA } \\
\text { ( g })\end{array}$ & $\begin{array}{c}\text { Combined mole of } \\
\text { nucleotide* }\end{array}$ \\
\hline A E A & 205 & $20-25$ & $4100-5125$ & 1.65 & $6765-8456$ & $21-26$ \\
A E C (a) & 249 & 25 & 6225 & 1.70 & 10583 & 33 \\
( b ) & , , & 100 & 24900 & 7.30 & 181770 & 566 \\
\hline
\end{tabular}

* Calculated as average molecular weight 321.

Table 1 indicates that 21-26 units of mononucleotides of y-RNA combined with 20-25 hexose units of AEA. In the case of the AEC : y-RNA complex, the combining amount of nucleotide was a little higher, but close to that of AEA. This might be explained by assuming that in addition the y-RNA combined with $\mathrm{NH}_{3}^{+}$groups bound at other positions than the primary hydroxyl group of the hexose units. From this result it was estimated that to some extent the complex contained a different complex with 3 molecules of $\operatorname{AEC}(\mathrm{n}=$

Abbreviations: AEA, Aminoethyl ether of amylose; AEC, aminoethyl ether of glycol cellulose; E-cell, Ehrlich ascites tumor cell; MA, methylated bovine serum albumin; PBS(-), phosphate buffered saline (without $\mathrm{Ca}^{2+}, \mathrm{Mg}^{2+}$ ); RFL, rat fibroblast cells; y-RNA, an RNA fraction isolated from yeast. 
25) linked with one chain of y-RNA. However, in the case of the complex composed of $\operatorname{AEC}(n=100)$ the amount of combining RNA was in a remarkably high concentration, so that the linkage in this complex was presumably different from that of the complex composed of the low polymer. For example, it may have contained the complex in which only one side of y-RNA combines with the polymer. This fact also implies that for the complex formation it is necessary to mix AEA or AEC with excess RNA. In the contrary situation it is likely to build up something like the complex formed from $\operatorname{AEC}(n=100)$.

3) Mice

Female mice (ddN) of an inbred strain, weighing 18-26 g, were obtained from the Animal Center, Kyushu University.

\section{4) Tumor cells and their treatments}

Ehrlich ascites tumors were given i.p. and maintained in this inbred strain, as described previously (Maekawa and Kushibe, 1972). The conditions of tumor cell treatment with the complex and of the challenge inoculation were the same as those already reported.

\section{5) Dissociation of AEA : $y-R N A$ complex in acidic solution}

An AEA : y-RNA complex was prepared from $3 \mathrm{ml}(34.2 \mathrm{mg})$ of AEA (at $\mathrm{pH}$ 7.0) and excess y-RNA (113 mg), (combining ratio of AEA: y-RNA was 1: 1.7), washed thoroughly with water. The washed complex was suspended in buffer solution ( $\mathrm{ACOH}-\mathrm{AcONa}$ and $\mathrm{HCl}-\mathrm{AcONa}$ ), then repeatedly washed with the same buffer solution, until $\mathrm{A}_{260 \mathrm{~nm}}$ of the supernatant became constant. From the A,,,, of all washed solutions, the quantity of dissociated RNA was calculated. The results were as illustrated in Fig. 1.

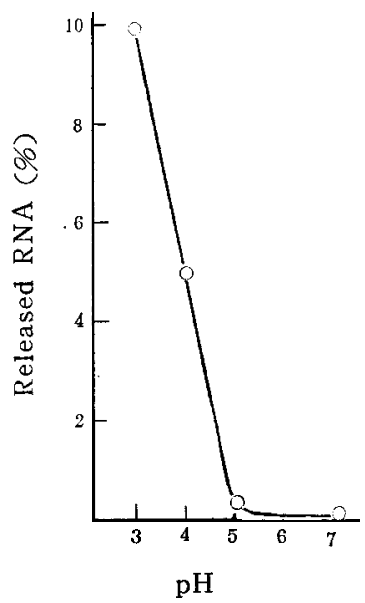

Fig. 1. Apparent dissociation of AEA: y-KNA complex.

\section{6) Hydrolysis of AEA : y-RNA complex by RNase A}

An aqueous suspension (mg/ml) of AEA : y-RNA complex (1 :1.7wt./wt.) was used. To this suspension $(1 \mathrm{ml}), 0.5 \mathrm{ml}(1.4 \mathrm{mg})$ of bovine pancreatic 
RNase A (Mann Research Lab.), which had been dissolved in $0.1 \mathrm{M}$ tris- $\mathrm{HCl}$ buffer (pH 7.5), was added and incubated for 2 hours at $37^{\circ} \mathrm{C}$ with shaking. Then $0.5 \mathrm{ml}$ of trichloroacetic acid $(2.5 \%)$ was added, and the solution was allowed to stand for $30 \mathrm{~min}$. at $0^{\circ} \mathrm{C}$. The acid soluble fraction and the precipitate were separated after centrifugation. The phosphate content of the former was determined by the method of Allen (1940). The results showed that the digestivity of AEA : y-RNA complex decreased $49 \%$, as compared with that of the RNA.

The phosphate content of AEA : y-RNA complex $4.5 \%$

The phosphate content of the acid soluble fraction separated from the complex after RNase A treatment

Phosphate liberated on a control experiment (without RNase A) . . . .0.9\%

Therefore, it was calculated that the RNA composed of the AEA: y-RNA complex was hydrolyzed to $\left(\frac{3.1-0.9}{4.5} \times 100=\right) 48.8 \%$.

$\operatorname{AEC}(n=25): y-R N A$ complex was estimated in the same manner, the digesting ratio being similar to that of the AEA : y-RNA complex. The AEC $(n=100)$ : y-RNA complex was not estimated.

\section{RESULTS}

\section{1) Toxicity of AEA and AEC}

The AEA : y-RNA and AEC : y-RNA complexes scarcely exhibited any toxicity to mice, whereas injection of AEA alone revealed considerable toxicity. That is, when $4.0 \mathrm{mg}$ of AEA initially adjusted to $\mathrm{pH} 7.2$ was injected intra* peritoneally into 5 mice, all of them died in 1-2 hours. The effects of $\operatorname{AEC}(\mathrm{n}=$ 25) were similar to those of AEA.

\section{2) The effectiveness of AEA to E-cells (in vitro)}

E-cells were suspended in PBS( - ) to obtain a concentration of $8 \times 10^{7}$ cells $/ \mathrm{ml}$. $0.01 \mathrm{ml}$ of the E-cell suspension and AEA $0.5 \mathrm{ml}$ of variable concentrations were mixed and incubated for 2 hours at room temperature. Afterwards, by adding $1.5 \mathrm{ml}$ of nigrosine to the mixture, living and dead cells were estimated by using the Bürker-Türk haematometer. The results are displayed in Table 2 .

Table 2. Cytocidal activity of AEA in vitro.

\begin{tabular}{ccc} 
Amount of AEA in testing mixture & Relative conc. of AEA & Cytocidal activity (\%) \\
\cline { 2 - 3 }$(0.51 \mathrm{ml})$ & & 0.01 \\
$0.114 \mu \mathrm{g}$ & 0.05 & 0.9 \\
$0.507 \mu \mathrm{g}$ & 0.1 & 7 \\
$1.14 \mu \mathrm{g}$ & 0.2 & 54 \\
$2.8 \mu \mathrm{g}$ & 0.5 & 100 \\
$5.7 \mu \mathrm{g}$ & 1 & $100 "$ \\
$11.4 \mu \mathrm{g}$ & 10 & \\
$114.0 \mu \mathrm{g}$ &
\end{tabular}




\section{3) The action of AEA : $\mathbf{y}$-RNA complex on E-cells and RFL-cells}

The procedure employed was similar to that described in 2), except the incubation time was variant. The results are given in Table 3 . A 20 min. incubation period and an amount of $3.2 \mathrm{mg}$ of AEA : y-RNA complex seemed to be insufficient to attenuate E-cells, while cytocidal activity was clearly apparent at twice the dose and incubation for 2 hours. It was therefore, assumed that the longer the incubation time, the more complex that dissociated, and the more cytocidal activity of AEA that appeared. On the other hand, the complex exhibited cytocidal activity against rat fibroblast cells (RFL-cell line) to a much lower extent than against E-cells.

Table 3. The effects of mixing amounts and duration of incubation on cytocidal activity of AEA : y-RNA complex.

\begin{tabular}{|c|c|c|}
\hline $\begin{array}{l}\text { Amounts of AEA : y-RNA complex } \\
\text { in the testing mixture }(0.51 \mathrm{ml})\end{array}$ & $\begin{array}{l}\text { Duration of } \\
\text { incubation } \\
\left(\text { at } 37^{\circ} \mathrm{C}\right)\end{array}$ & $\begin{array}{c}\text { Cytocidal activity* } \\
(\%)\end{array}$ \\
\hline $\begin{array}{l}3.2 \mathrm{mg} \\
6.4 \mathrm{mg}\end{array}$ & $\begin{array}{r}20 \text { min. } \\
120 \text { min. } \\
20 \text { min. } \\
120 \text { min. }\end{array}$ & $\begin{array}{r}1.3 \\
2.1 \\
14.3 \\
38.4\end{array}$ \\
\hline $6.4 \mathrm{mg}$ & $120 \mathrm{~min}$. & $\begin{array}{l}\text { RFL-cells } \\
9.7 \text { (fibroblast of rat) }\end{array}$ \\
\hline
\end{tabular}

* Living cells in control-living cells in test $\times 100$

\section{4) Inhibition of tumor transplantation by treatment with AEA (or AEC) : y-RNA complex}

(a) The experimental results relating to the treatment with AEA : y-RNA complex are shown in Table 4. Thus, the effects of attenuating E-cells with the complex were examined in the dose range of $3.2 \mathrm{mg} / \mathrm{animal}$ to $26.7 \mathrm{mg}$ / animal. Each concentration was effective in causing 85-100\% inhibition in the transplantation. Moreover, the mice treated were resistant against challenge inoculation afterwards.

From Table 4, it is clear that a high concentration of AEA : y-RNA complex

Table 4. Effects of AEA : y-RNA complex on transplantability of Ehrlich ascites tumor cells.

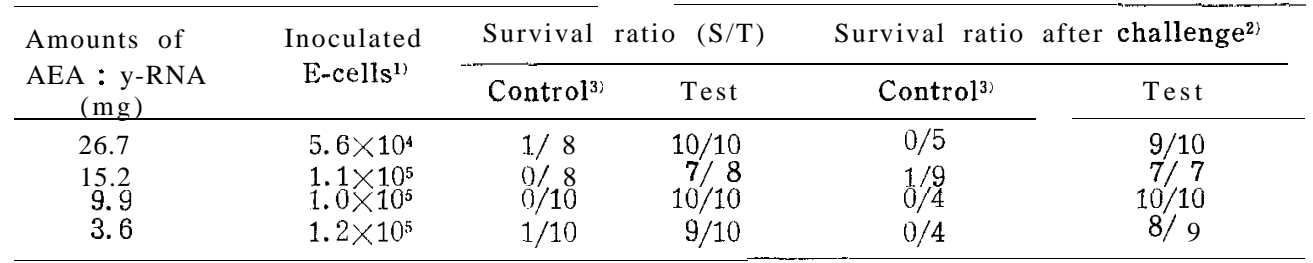

1) Inoculated after incubation for $20 \mathrm{~min}$. at $25^{\circ} \mathrm{C}$ with AEA : y-RNA complex.

2) In 31 days after treatment, $1.0 \times 10^{5}$ of E-cells were challenged.

3) PBS(-) alone was applied.

$\mathrm{S}$, survival mice; $\mathrm{T}$, test mice. 
Table 5. Effects of $\operatorname{AEC}(n=25): y-R N A$ complex on transplantability of Ehrlich ascites tumor cells.

\begin{tabular}{lcccc}
\hline \multicolumn{1}{c}{ Group } & $\begin{array}{c}\text { Amounts of } \\
\text { complex applied }\end{array}$ & $\begin{array}{c}\text { Inoculated } \\
\text { E-cells }\end{array}$ & $\begin{array}{c}\text { Survival } \\
\text { ratio (S/T) }\end{array}$ & $\begin{array}{c}\text { Survival ratio } \\
\text { after challenge }\end{array}$ \\
\hline AEC $(\mathbf{n}=25): \mathrm{y}-\mathrm{RNA}$ & $15.2 \mathrm{mg}$ & $1.5 \mathrm{X} 105$ & $10 / 11$ & $8 / 10$ \\
Control & - & & $0 / 10$ & $0 / 4$ \\
\hline
\end{tabular}

1) Inoculated after incubation for $30 \mathrm{~min}$. at $25^{\circ} \mathrm{C}$ with $\mathrm{AEC}(\mathrm{n}=25)$ : $\mathrm{y}$-RNA complex.

${ }^{2)}$ In 30 days after treatment, $1.5 \times 10^{5}$ of E-cells were challenged.

is not always necessary, and that there is no bad effect by using large quantities. (b) The effects of attenuating E-cells by $\operatorname{AEC}(n=25)$ : y-RNA complex are shown in Table 5. A $90 \%$ attenuation was achieved, that is, ten to eleven mice survived. Furthermore, eight to ten mice were resistant to the challenge inoculation afterwards. Compared with the results given in Table 4, it is clear that there are little differences between the two methods, that is, the effects did not differ much by changing the configuration of the constituent saccharide (steric structure).

(c) The effects of attenuating E-cells by $\operatorname{AEC}(n=100)$ : $y$-RNA complex are indicated in Table 6 .

This complex floated in $0.9 \% \mathrm{NaCl}$ solution, and was difficult to mix with E-cells. The molecular weight of the complex was so large that the viscous liquid was difficult to inject into mice. The results were therefore uncertain. It seems that the effects of $\operatorname{AEC}(n=100): y-R N A$ complex were inferior to those of AEA or AEC $(n=25)$ : $y$-RNA complex, probably because of the difficulty in using the former.

Table 6. Effects of $\operatorname{AEC}(n=100): y-R N A$ complex on transplantability of Ehrlich ascites tumor cells.

\begin{tabular}{|c|c|c|c|c|}
\hline Group & $\begin{array}{l}\text { Amounts of } \\
\text { complex applied }\end{array}$ & $\begin{array}{l}\text { Inoculated } \\
\text { E-cells }\end{array}$ & $\begin{array}{l}\text { Survival } \\
\text { ratio (S/T) }\end{array}$ & $\begin{array}{l}\text { Survival ratio } \\
\text { after challenge }{ }^{11}\end{array}$ \\
\hline $\begin{array}{l}\text { AEC }(n=100) \\
\text { y-RNA complex }\end{array}$ & $14.7 \mathrm{mg}$ & $\begin{array}{l}2 \text { heads } \\
1.2 X 105 \\
2 \text { heads } \\
9.3 \mathrm{X} 104 \\
8 \text { heads } \\
1.3 \times 10^{5}\end{array}$ & i & $4 / 10$ \\
\hline Control & - & $1.2 \times 10^{5}$ & $0 / 10$ & $0 / 5$ \\
\hline
\end{tabular}

1) Mice were inoculated with $1.3 \times 10^{5}$ E-cells in 31 days after the treatment.

5) Therapeutic effects of AEA (or AEC) : y-RNA complex

In attenuating E-cells as described, the effects of the AEA : y-RNA complex injection were examined to elucidate the mechanism of action of the complex. After $1.3 \times 10^{5}$ cells/mouse were implanted intraperitoneally, one group was injected with $5 \mathrm{mg}$ AEA: y-RNA complex/mouse daily for 5 days from the first day onwards; a second group was injected daily for 5 days from the 3rd day onwards; and a third group was treated daily for 5 days from the 5 th day 
onwards. Each $5 \mathrm{mg}$ AEA : y-RNA complex was suspended in $0.2 \mathrm{ml}$ of physiological saline solution $(0.9 \% \mathrm{NaCl})$ and injected i.p. The results are shown in Table 7 .

As seen from Table 7 , the complex displayed certain inhibitory effects on the implantation and multiplication of E-cells. Especially in the group that received the complex within 24 hours after E-cell transplantation, prevention was almost complete. Furthermore, the inhibiting effect was mainly apparent following early treatment, there being no appreciable effect on the mice in which the multiplication of E-cells had proceeded and the ascites emerged.

Table 7. Effects of AEA : y-RNA on transplantability and repression of Ehrlich ascites tumor cells.

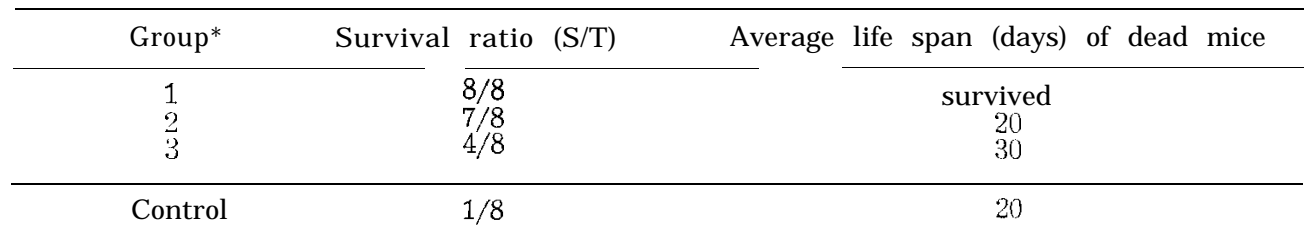

* Mice were inoculated with 1.3 105 E-cells.

1.: $5 \mathrm{mg}$ of AEA : y-RNA (in $0.2 \mathrm{ml}$ of $0.9 \% \mathrm{NaCl}$ solution) was administered i.p. once daily starting 24 hours after inoculating tumor cells (total: 5 times).

2: Same procedure was done from 72 hours after inoculating tumor cells (total:

5 times).

3: Same procedure was done from 120 hours (total: 5 times).

\section{DISCUSSION}

AEA or AEC in which the degree of polymerization was about 20-25 and consequently the molecular weight was 5-6000, was mixed with y-RNA in a region of excess $\mathrm{y}$-RNA to obtain a complex of an approximately constant molar ratio. The combining ratio was $1: 1.65-1.7 \mathrm{~g} / \mathrm{g}$ in the AEA as well the AEC: $y$-RNA complex. On the other hand, $\operatorname{AEC}(n=100)$ showed an abnormally high combining ratio, suggesting that the mode of complex formation was different from the other two.

These complexes dissociated $5 \%$ at pH 4.1 which was the isoionic point of the tumor surface, and were hydrolyzed about $49 \%$ by pancreatic RNase A.

When E-cells were incubated with these complexes the transplantability of E-cells in mice was almost completely inhibited. Thus, pretreated mice becamc strongly resistant to a challenge inoculation afterwards. There was hardly any difference by changing the configuration of saccharide. The effects of AEC : y-RNA complex seemed to be slightly better than that of AEC : y-RNA complex, because the viscosity of AEA was lower than that of AEC, and the reaction proceeded homogeneously.

Some published approaches involve the conversion of an inactive drug to an active metabolite in the more acidic microenvironment surrounding tumor cells (Friedkin, 1973; Papanastassiou et al., 1966; Stevens and Mosteller, 1969).

It appeared that RNA was linked to AEA or AEC by ionic linkages, and 
that the toxicity of the latter was masked by linking with RNA. Therefore, it might be inferred that the attenuation of E-cells caused by incorporation of these complexes mainly ascribed to AEA or AEC.

Furthermore, it is suggested that a shorter AEA or AEC molecule, or a more dissociable one at $\mathrm{pH} 4.1$ than the present compounds might be more effective. We believe this approach warrants further investigation.

\section{REFERENCES}

Allen, R. J. L. 1940 The estimation of phosphorus. Biochem. J., 34: 858-865

Friedkin, M. 1973 The biochemist's outlook on cancer research. Feder. Proc., 32: 2148 2153

Higuchi, M., I. Sakata and R. Senju 1970 Kinetic study on Hofmann reaction of carbamoylethyl starch. Kogyo Kagaku Zasshi, 73: 421-430

Maekawa, K. and M. Kushibe 1972 Repression of propagation of Ehrlich ascites tumors by means of attenuating tumor cells. Cancer, 30: 366-372

Maekawa, K. and A. Momii 1972 Repression of propagation of Ehrlich ascites tumors by means of attenuating tumor cells. II. Proc. Jap. Acad., 48: 690-694

Papanastassiou, Z. B., R. J. Bruni, E. White and P. L. Levins 1966 Potential carcinolytic agents. IV. Diazoamino mustards. J. Med. Chem., 9: 725-729

Straumfjord, J. V. and J. P. Hummel 1959 Microelectrophoresis of ascites tumor cells and the effect of polyxenyl phosphate. Cancer Res., 19: 913-917

Stevens, C. D. and R. C. Mosteller 1969 Enhancement by glucose of the inhibition of an Ehrlich ascites tumor by tetraazotricyclododecene. Cancer Res., 29: 1132-1136

Takakuwa, M., Y. Tamai, 0. Ochi and M. Kushibe 1975 Resistance against Ehrlich ascites tumor induced by DEPC-treated Ehrlich cells. Agr. Biol.Chem., 39: 701-706 